\title{
Water regulation on sewed lands of Western Polissya
}

N. Mozol

Institute of Water Problems and Land Reclamation NAAS

* Scientific supervisor - candidate of technical Sciences Yatsyk Mykola V.

The purpose. To study an opportunity of provision of stable and optimum water regime of soils on sewed lands irrespective of geomorphologic and climatic conditions of Western Polissya. Methods. Statistical, field, laboratory. Results. The technique is tested of water regulation on sewed lands which is based on accumulation of local drainage effluent by means hydrolevel controller of ground waters of complex action adapted for conditions land forms. Conclusions. Study of efficiency of application of mechanically-technological provisions on regulation of WR have proved that in conditions of insufficient watering it is possible to sustain optimum water regime of soils on sewed lands $(0,55-1,1)$ by accumulation of local flow and remodeling collector-drainage net.

Key words: land forms, water regulation of soil, collector ditch, hydroadjuster.

At the end of the 20th century in Ukraine there were built a large number of drainage systems on the area of more than 3.2 million hectares, of which drying and 2,2 million ha. Only in the Western Polissya drainage system located on an area of over 0,8 million ha [1]. Inefficient functioning systems, human pressure on reclaimed agricultural landscapes, particularly land improvement and agronomic measures entail negative processes change the surface condition and structure of soil compaction and subsidence. The main disadvantage of these designs is that they work in cycles, diversion of excess water drying array of alternate feed it to decrease the wetting through or lockup channel gateways water levels in the main and side channels. This permanently assigned almost all spring and summer stormwater runoff, which can not be regulate. A characteristic feature of the water-air regime of soil in reclaimed areas at specified the system is excessive waterlogging straight lowland areas and flooding humble landscape elements with relatively favorable water and air conditions in areas of high relief.

The total area of territories subject to degradation as a result of these processes is more than 0,7 million ha, of which the West Polissya - about 0,22 million hectares [2]. Just beyond the zone of Western Polissya of Ukraine allocated more than half of the annual runoff, which leads to disruption of natural hydrological and geomorphological conditions.

The aim of this work is to study the possibility of sustainable and optimal water regime of soils of the reclaimed area, regardless of the geomorphological and climatic conditions.

The working hypothesis of these studies was the approval of the regulation of the groundwater level separately on each link a regulatory or transport network within the reclamation system expressed in local swampy depressions.

Analysis of recent researches and publications. The results of analytical studies, mainly reflecting the results of studies of neighboring countries, the International Commission for Irrigation and Drainage, the Department of Social and Economic Rights Council showed that most countries in whole or in part (for certain areas) built card speakers available degradation processes of secondary swamping areas due to inefficient functioning drainage systems [3-4]. But filling methodology and building map data is not standardized, each country determines criteria and factors in using individual solutions to problems of water regime of soil reclaimed land.

Problems of development and utilization of water resources for water regime in land reclamation systems in the area of Polissya Ukraine also devoted several works of scientists: Kovalenko P.I., Skrypnyk O.V., Yanhol A.M., Yatsyk A.V. [5-7] etc. One of the main methods of land reclamation to ensure full use of reclaimed agricultural landscapes and creating favorable conditions for mechanization 
of farm work proposed construction of operational planning or the so-called territory rocker alignment. An analysis of the economic component of planning - to increase crop-planned reclaimed area does not compensate for the cost of its arrangement.

Research methods. The common methods used in empirical and theoretical levels of research, in particular: systemic approach in the study of the relationship between phenomena and processes of rewetting, experiment - research of regularities of functioning of drainage systems typical drainage systems.

Full-scale studies in 2014-2016 at the experimental site reclamation systems research station Sarny IWPiM NAAS (Rivne region) had complex character and carried on experimental modular sections in areas controlled by separate drainage collectors (Figure 1).

Linking between the level of ground water, precipitation and runoff drainage module carried conducting measurements of actual values of parameters and processing of observations using the methods of mathematical statistics [8-9].

Results. Given the heterogeneity of space (relief) accumulative Polissya lowland, in the absence of guaranteed sources of water to wet crops the improved technology, which is based on the accumulation and utilization of local drainage runoff through the use of adapted to the conditions of the relief toregulate groundwater level complex actions [10].
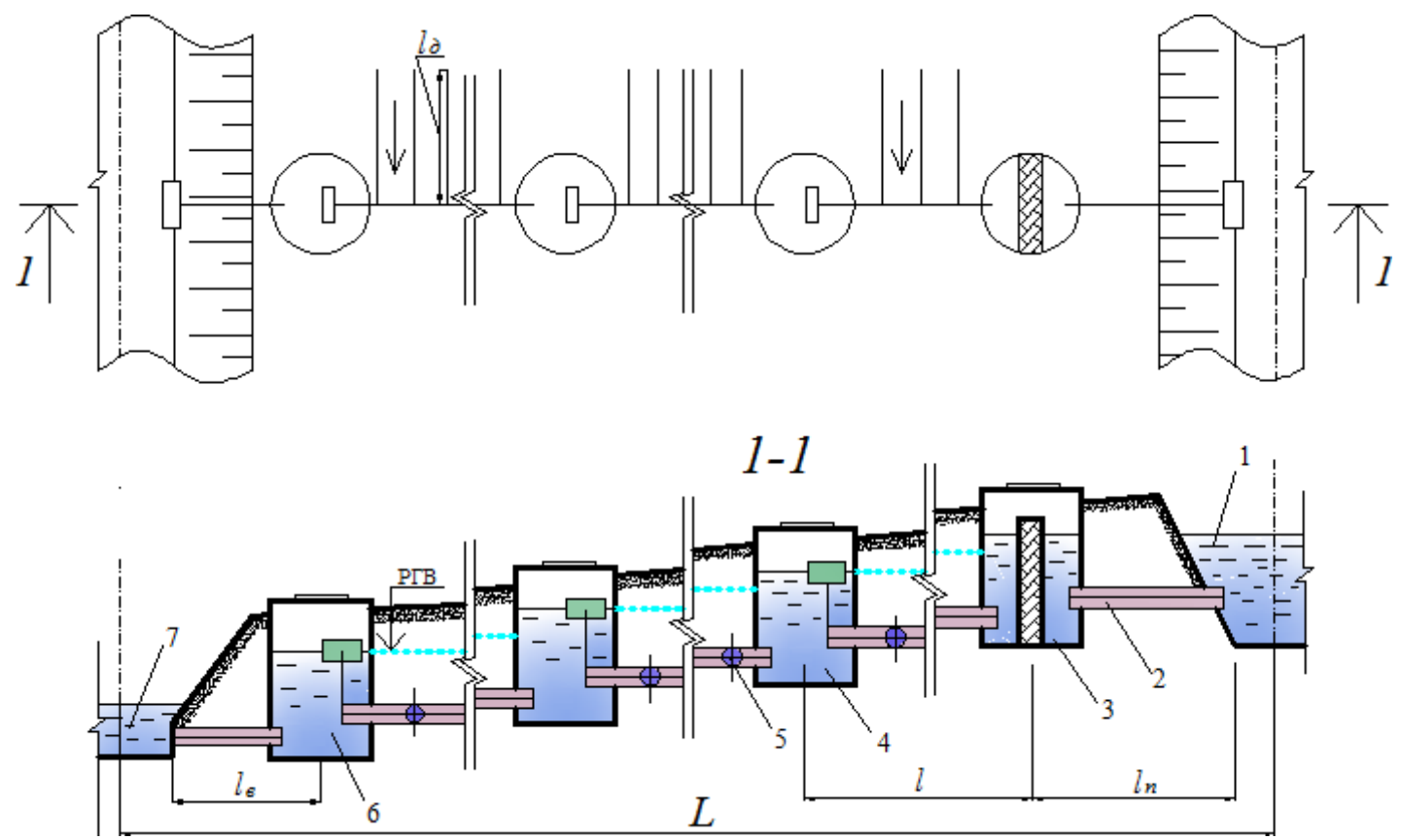

Water source, drain collector 2; 3-Outlet with grill; 4 The regulatory structure; 5 Drains; 6- Outfall regulating structure; 7 Water intake $L$ - Total length of the collector; I - Length of the reservoir level; $L P$ Long underwater pipeline; Lv - Length of drainage pipe; Id - Length drains

Fig. 1. Scheme Regulation RGV in canals and drainage collectors drying-wetting network

Module drainage runoff volume determined way. Adjusting drainage runoff was conducted in the spring and summer (growing) period. For moistening the soil collector 2Dr was found hidrorehulyator complex action (Fig. 2). For comparison, measurements and observations conducted at the test collector $1 \mathrm{Dr}$. 


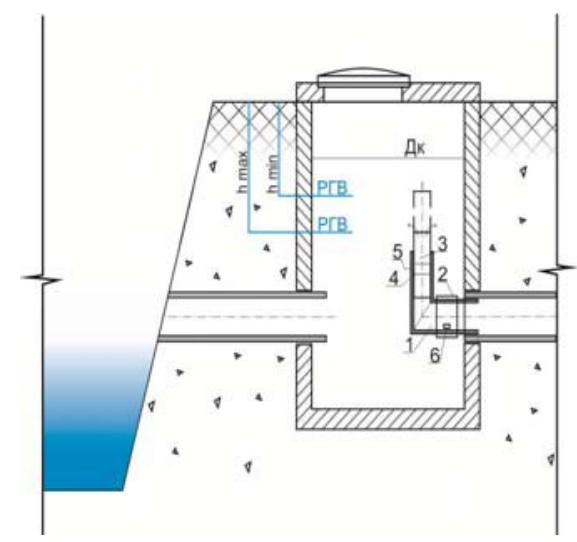

1 - the case; 2 - stop organ; 3 - trumpet; 4 - O-ring; 5 - the catch; 6 - outlet

Fig. 2. Hidrorehulyator ground water level complex action

All components of the proposed hidrorehulyator made of polyethylene, which minimizes the cost and increases the life of the times. Adjust the set water level is realized by moving in the housing 1 vertical pipes 3 and its fastening clamp 5. Hidrorehulyator installed in inspection and intermediate wells in the mouth of the drainage collector. When the device such wells should take into account the requirement that the maximum elevation surface areas controlled collector should not exceed the permissible deviation from the recommended norm drainage. After discharge excess water in the spring of translated regulator in operation to stabilize a given $\mathrm{R} Ґ \mathrm{~V}$ ceiling outlet 6 in its housing 1. Thus, the drained lands in the area of the collector, held accumulation drainage runoff.

Fig. $3 \ldots 4$ presents the results of measurements of groundwater levels in the growing season at the collector with adjustable drain flow (2Dr) and the control manifold (1Dr). The growing season was characterized in 2016 as "dry" rainfall was $185 \mathrm{~mm}$. It was established that the regulated areas groundwater level in April fluctuated in the range of $0.55 \ldots 0.83 \mathrm{~m}$, May and June $-1.00 \ldots 1.13 \mathrm{~m}$ from the surface. In the control region in the same period RGV changed within $1.08 \ldots 1.55 \mathrm{~m}$ with drainage runoff dynamics averaged $0.12 \ldots 0.04 / \bullet \mathrm{c} / \mathrm{ha}$.

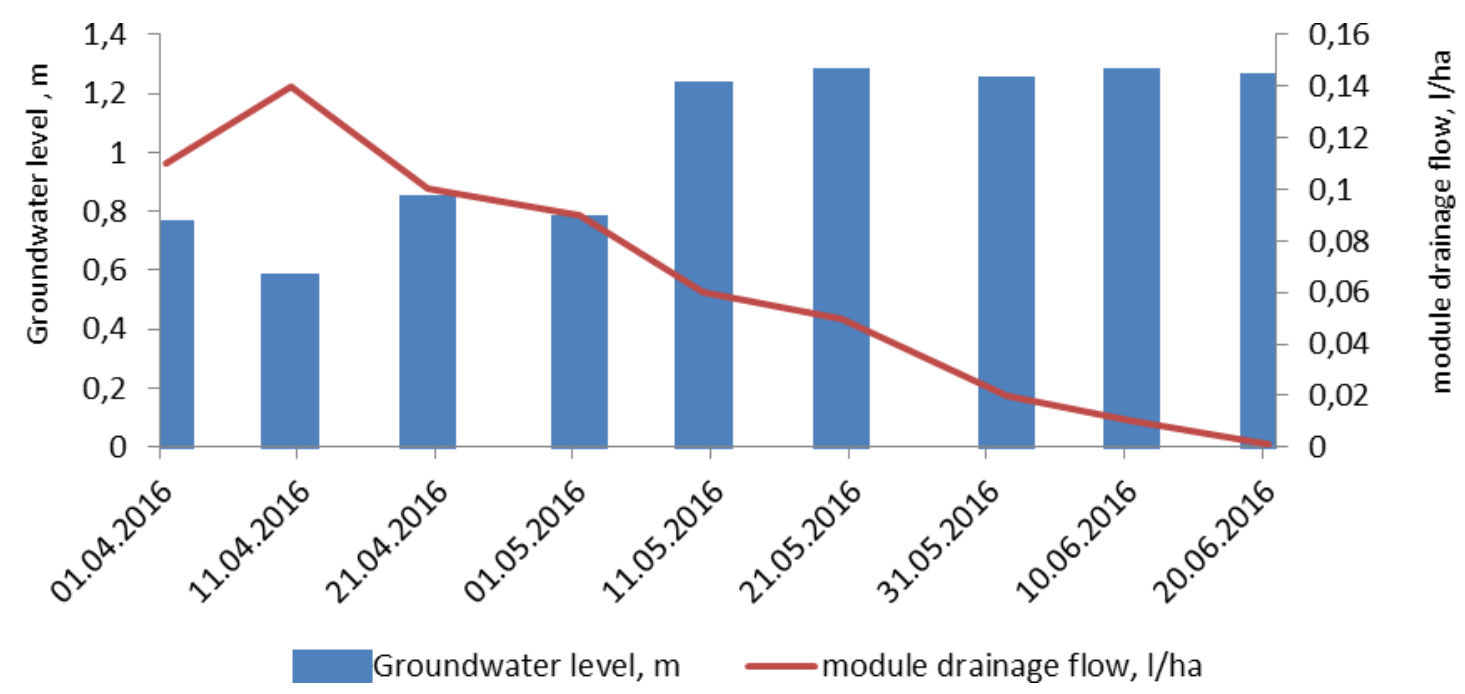

Fig. 3. Groundwater level dependence of drainage runoff module, 2-dr 


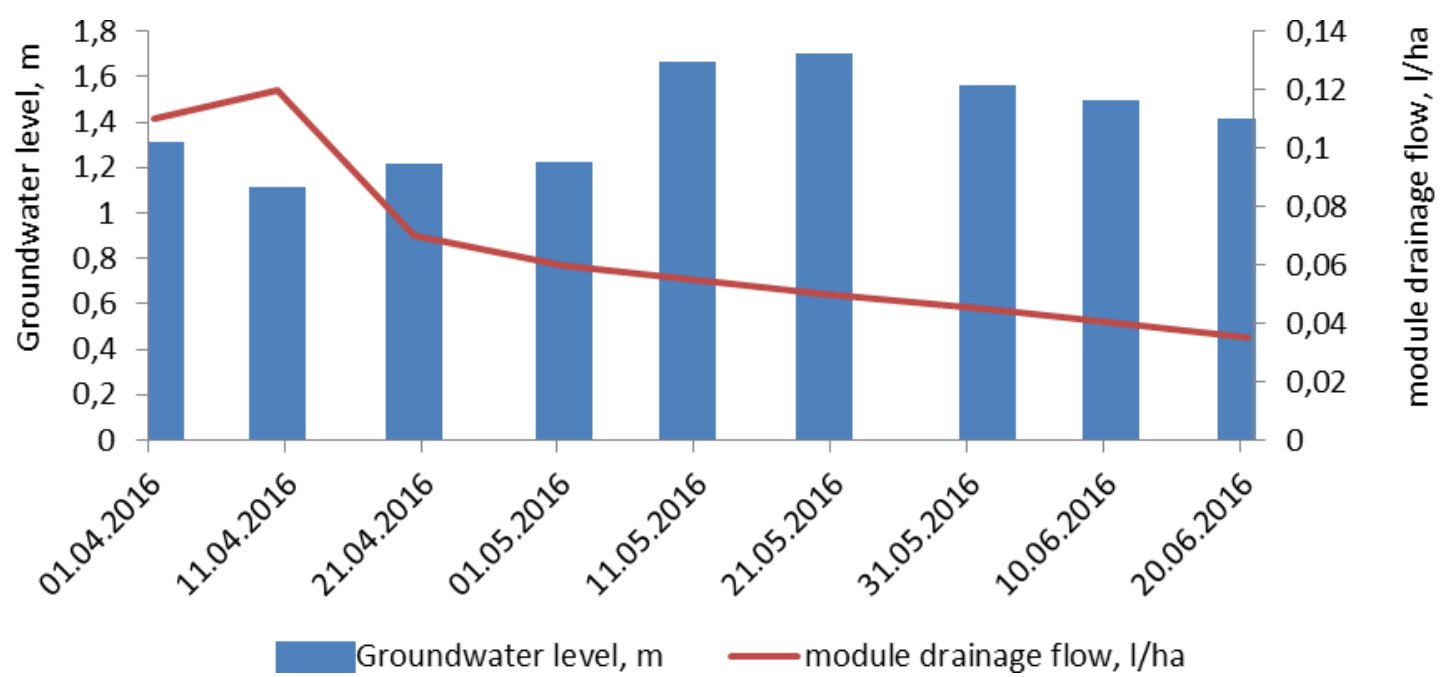

Fig. 4. Groundwater level dependence of drainage runoff module, 1-dr

\section{Conclusions}

The results of experimental studies carried out on reclaimed land, the complicated local swampy depressions demonstrated the effectiveness of using adapted comprehensive toregulate steps to regulate groundwater. The proposed technological activities are based on the accumulation of local runoff and modernization of the drainage network to ensure optimal water regime of drained soils in the absence of guaranteed additional sources of moisture. The groundwater level at the site of the system equipped toregulation complex action, during the growing season ranged from $0,55 \ldots 1.10 \mathrm{~m}$, which corresponds to the rate of drainage of most of the cultivated region of crops.

\section{References}

1. The concept of the effective use of drained lands in humid zone of Ukraine (the scientific basis) / Romashchenko, N. And. [et al.]; IWPiM NAAS, NSC "Institute of agriculture" NAAS, NSC "IG name. Sokolovsky" NAAS etc. — K CPU "Komprint", 2015. - $22 \mathrm{sec}$.

2. Baluk S. A. Ecological state of soils of Ukraine / S.A. Baluk, V.V. Medvedev, N. M. Miroshnichenko, E.V. Skalnik, D.O. Timchenko, A.I. Fateev, A.O. Khristenko, Y.L. Tsapko // Ukrainian geographical magazine. - 2012, № 2. - P. 38-42.

3. Scientific edition. Progress in Managing Water for Food and Rural Development: Abstracts , Lviv, 17-24 may18-24, 2009 / the editorial Board: prof. Bart Schultz, etc.; - K., 2009.

4. Scientific edition. 22nd Congress International Commission on Irrigation and Drainage: Abstracts, Guanju, 13-20 sep. 2014 / the editorial Board: Benjamin Davis, etc.; - Tashkent, 2014.

5. Kovalenko P.I. Reconstruction of reclamation systems / Kovalenko P.I., Chaly B.I,, Tyshenko A,I, K .: Urozhay, 1991. - $168 \mathrm{p}$.

6. Yanhol A.M. Two-way humidity control in drying / Yanhol A.M. - M.: Kolos. - 1970. - 132 p.

7. Yatsyk A.V. The ecological situation in Ukraine and ways of its improvement - K .: Oriyana, 2003. $84 \mathrm{p}$.

8. Kornyeyenko S.V. Methods of hydrogeological investigations: a textbook / S.V. Kornyeyenko - K .: KNU. Shevchenko. - 2015. - $275 \mathrm{p}$.

9. ISO 7858-3: 2006 Measurement of water flow in closed conduits. Part 3: Test methods (ISO 78583: 1992, IDT).

10. Chaly B.I. Design of drainage systems block type / B.I. Chaly, Mozol N.V. // Water Management of Ukraine. - 2009. - №3. - S.55-56. 